\title{
PENGARUH PEMBERIAN BIOCHAR BATANG SINGKONG DAN PEMUPUKAN P TERHADAP SIFAT KIMIA TANAH ULTISOL YANG DITANAMI JAGUNG ( Zea mays L.)
}

\section{EFFECT OF GIVING CASSAVA STEM BIOCHAR AND P FERTILIZATION ON THE CHEMICAL PROPERTIES OF ULTISOL SOIL CORN PLANTED ( Zea mays L.)}

\author{
Febri Setiawan ${ }^{1 *}$, Sarno ${ }^{2}$, Nur Afni Afrianti ${ }^{2}$ dan Supriatin ${ }^{2}$

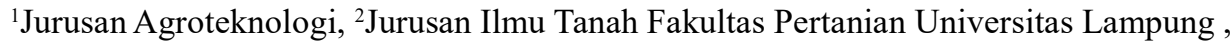 \\ Bandarlampung, Indonesia \\ Email: febrisetiawan.0405@gmail.com
}

*Corresponding Author, Diterima: 15 Okt. 2021 , Direvisi: 17 Nov. 2021 , Disetujui: 4 Jan. 2022

\begin{abstract}
Ultisol soil is one type of soil that is widely used for plant cultivation. However, Ultisol soil has many obstacles in its utilization because it is a soil that has low soil fertility. One of the efforts that can be done is by giving biochar and fertilization. The purpose of the study was to determine the effect of giving cassava stem biochar and the effect of $P$ fertilization on the chemical properties of Ultisol soil planted with corn ( Zea mays L.). The research was conducted in the integrated field of the Faculty of Agriculture, University of Lampung and Soil chemical analysis was carried out at the soil science laboratory Faculty of Agriculture, University of Lampung from January to July 2019. This study used a qualitative method arranged in a factorial ( $3 \times 3)$ which was applied in a Completely Randomized Group Design (RKTL) with 3 replications. The first factor was cassava stem biochar with doses 0 tons ha ${ }^{-1}, 2,5$ tons ha ${ }^{-1}$, dan 5 tons ha $a^{-1}$. The second factor is TSP fertilization at a doses $0 \mathrm{~kg} \mathrm{ha}^{-1}, 80 \mathrm{~kg} \mathrm{ha}^{-1}$, dan $160 \mathrm{~kg} \mathrm{ha}^{-1}$, then the data is presented using a curve to compare the chemical properties of the soil based on the treatment given. The results showed that the application of cassava stem biochar and P fertilization was able to increase total $N$ levels, $K$-dd levels, KTK and C-organic levels in Ultisol soil.
\end{abstract}

Keywords: Biochar, C-organic, K-dd levels, KTK, P fertilization, total N levels, ultisol soil.

\begin{abstract}
ABSTRAK
Tanah Ultisol merupakan salah satu jenis tanah yang banyak dimanfaatkan untuk budidaya tanaman. Namun demikian, tanah Ultisol memiliki banyak kendala dalam pemanfaatannya karena merupakan tanah yang memiliki kesuburan tanah rendah. Salah satu upaya yang dapat dilakukan adalah dengan pemberian biochar dan pemupukan. Tujuan penelitian adalah untuk mengetahui pengaruh pemberian biochar batang singkong serta pengaruh pempukan P terhadap sifat kimia tanah Ultisol yang ditanami jagung ( Zea mays L.). Penelitian dilakukan di lapangan terpadu Fakultas Pertanian Universitas Lampung dan analisis kimia tanah dilakukan di laboratorium ilmu tanah Fakultas Pertanian Universitas Lampung pada bulan Januari sampai dengan Juli 2019. Penelitian ini menggunakan metode kualitatif yang disusun secara faktorial ( 3 × 3$)$ yang diterapkan dalam Rancangan Kelompok Teracak Lengkap (RKTL) dengan 3 ulangan. Faktor pertama adalah biochar batang singkong dengan dosis 0 ton ha $\mathrm{ha}^{-1}, 2,5$ ton ha- ${ }^{-1}$, dan 5 ton ha ${ }^{-1}$. Faktor kedua adalah pemupukan TSP dengan dosis $0 \mathrm{~kg} \mathrm{ha}^{-1}, 80 \mathrm{~kg} \mathrm{ha}^{-1}$, dan $160 \mathrm{~kg} \mathrm{ha}^{-1}$, selanjutnya data disajikan dengan menggunakan kurva untuk membandingkan sifat kimia tanah berdasarkan perlakuan yang diberikan. Hasil penelitian menunjukkan bahwa pemberian biochar batang singkong dan pemupukan P mampu meningkatkan kadar N-total, kadar Kdd, KTK dan kadar C-organik pada tanah Ultisol.
\end{abstract}

Kata kunci: Biochar, C-organik, kadar N-total, kadar K-dd, KTK, pemupukan P, dan tanah ultisol 


\section{PENDAHULUAN}

Komoditas jagung mempunyai fungsi yang multiguna, yaitu sebagai pangan (food), pakan (feed), dan bahan baku industri (fiber). Jagung merupakan komponen utama dalam ransum pakan ternak terutama unggas dengan proporsi sekitar $60 \%$. Diperkirakan lebih dari 58\% kebutuhan jagung dalam negeri digunakan untuk pakan, sedangkan untuk pangan hanya sekitar 30\% (Kasryno et al., 2008).

Tanah Ultisol merupakan salah satu jenis tanah yang banyak dimanfaatkan untuk budidaya tanaman, salah satunya yaitu jagung. Hal ini dikarenakan tanah Ultisol tersebar cukup luas di Indonesia. Namun, tanah Ultisol memiliki banyak kendala dalam pemanfaatannya karena merupakan tanah yang memiliki tingkat kesuburan yang rendah. Menurut Fitriatin et al.,(2014), Mulyani et al., (2010), dan Prasetyo dan Suriadikarta (2006), tanah Ultisol memiliki kemasaman tanah tinggi, kandungan bahan organik, hara makro dan mikro yang rendah, KTK rendah, kandungan Al tinggi serta peka terhadap erosi sehingga kesuburan tanah rendah.

Salah satu unsur hara makro yang rendah ketersediaannya di tanah Ultisol adalah unsur hara P. Hal ini dikarenakan unsur hara $P$ terikat oleh unsur Al dan Fe yang tersedia tinggi di tanah Ultisol. Menurut Maulana et al. (2014), unsur P yang diberikan ke dalam tanah masam tidak dapat digunakan secara optimal oleh tanaman. Hal ini disebabkan karena tanah Ultisol memiliki $\mathrm{pH}$ yang rendah, sehingga mengandung unsur logam seperti Al dan Fe yang tinggi. Hal ini menyebabkan adanya reaksi antara unsur $\mathrm{P}$ dengan unsur logam tersebut di dalam tanah dan menyebabkan ketersediaan $\mathrm{P}$ pada tanah ini rendah.

Salah satu upaya yang dapat dilakukan adalah dengan pemupukan. Pemupukan memiliki peran yang sangat penting dalam produksi tanaman pertanian, pemupukan dapat dilakukan dengan cara mengkombinasikan pupuk organik dengan anorganik untuk meminimalisasi input dan residu pupuk anorganik dalam produksi, namun tetap mencukupi unsur hara yang sesuai kebutuhan tanaman serta memperbaiki sifat tanah (Roosmarkam dan Yuwono, 2002).

Menurut Hafiz et al. (2016), bahan organik dapat meningkatkan ketersediaan $\mathrm{P}$ tanah dimana bentuk organik pada bahan organik diubah ke bentuk anorganik dengan bantuan mikroba selama proses dekomposisi. Salah satu contoh bahan organik yang dapat diberikan yaitu biochar.
Menurut Gani (2009), biochar merupakan arang kayu berpori (porous) yang digunakan sebagai suatu pembenah tanah. Biochar dapat meningkatkan produktivitas serta retensi dan ketersediaan hara bagi tanaman. Gani (2010) juga menyatakan bahwa penambahan biochar ke dalam tanah akan meningkatkan ketersediaan kation utama, N-total, P dan KTK yang berakibat pada peningkatan produktivitas tanaman. Tingginya ketersediaan hara bagi tanaman merupakan hasil secara langsung dari biochar, sehingga menyebabkan meningkatnya retensi hara. Biochar memiliki keunggulan yang lebih efektif dari pada bahan organik lain, yaitu mampu menahan unsur hara sehingga meningkatkan ketersediaannya bagi tanaman dibandingkan bahan organik lain.

Penelitian ini dilakukan untuk mengetahui pengaruh pemberian biochar batang singkong serta pengaruh pempukan $\mathrm{P}$ terhadap sifat kimia tanah Ultisol yang ditanami jagung (Zea mays L.)

\section{BAHAN DAN METODE}

\subsection{Waktu dan Rancangan Percobaan}

Penelitian dilakukan di Laboratorium Lapangan Terpadu Fakultas Pertanian Universitas Lampung dan analisis kimia tanah dilakukan di Laboratorium Ilmu Tanah Fakultas Pertanian Universitas Lampung. Pembuatan biochar dilakukan di Balai Penelitian Tanah Kebun Percobaan Taman Bogo Purbolinggo Lampung Timur. Penelitian dilakukan 6-7 bulan dimulai dari bulan Januari 2019 - Juli 2019.

Penelitian ini menggunakan metode kualitatif yang disusun secara faktorial ( 3 x 3 ) yang diterapkan dalam Rancangan Kelompok Teracak Lengkap (RKTL) dengan 3 ulangan. Faktor pertama adalah biochar (B) dengan dosis 0 ton $\mathrm{ha}^{-1}(\mathrm{~B} 0), 2,5$ ton ha $\mathrm{a}^{-1}(\mathrm{~B} 1)$, dan 5 ton $\mathrm{ha}^{-1}(\mathrm{~B} 2)$. Faktor kedua adalah pemupukan TSP dengan dosis $0 \mathrm{~kg} \mathrm{ha}^{-1}(\mathrm{P} 0), 80 \mathrm{~kg} \mathrm{ha}^{-1}(\mathrm{P} 1)$, dan $160 \mathrm{~kg} \mathrm{ha}^{-1}(\mathrm{P} 2)$, dengan kandungan $\mathrm{P} 2 \mathrm{O} 5$ dalam TSP sebesar $45 \%$ yaitu P2O5 $0 \mathrm{~kg} \mathrm{ha}^{-1}, 36 \mathrm{~kg} \mathrm{ha}^{-1}$, dan $72 \mathrm{~kg} \mathrm{ha}^{1}$.

\subsection{Pembuatan Biochar}

Pembuatan biochar dilakukan di Balai Penelitian Tanah Kebun Percobaan Taman Bogo Lampung Timur. Pembuatan biochar menggunakan limbah batang singkong yang sudah tidak digunakan, yaitu bagian bonggol dan batang yang tidak dapat dijadikan sumber bibit untuk pertanaman singkong selanjutnya. Alat yang 
digunakan untuk pembuatan biochar adalah Adam Retort Kiln (ARK), yaitu alat pembuat biochar yang dapat mengolah bahan baku dalam jumlah besar.

\subsection{Pelaksanaan Percobaan}

\subsubsection{Pengolahan tanah}

Sebelum dilakukannya pengolahan tanah, lahan perlu dibersihkan terlebih dahulu. Pembersihan dilakukan dengan alat pemotong rumput untuk memudahkan pengolahan tanah selanjutnya. Pengolahan tanah dilakukan dengan hand traktor. Tanah dibajak dua kali, lalu digaru satu kali. Setelah itu dibuat petakan dengan ukuran $3 \times 3 \mathrm{~m}$. Jarak antar ulangan $1 \mathrm{~m}$, sedangkan jarak antar perlakuan $0,5 \mathrm{~m}$.

\subsubsection{Pengaplikasian biochar}

Aplikasi biochar dilakukan setelah pengolahan tanah dan pembuatan petak selesai. Aplikasi biochar dilakukan dengan cara dilarik, yaitu dengan membuat lubang memanjang pada baris tanam di lapangan. Selanjutnya, biochar diletakkan di atas permukaan tanah yang sebelumnya telah dilarik, kemudian dibenamkan ke dalam tanah dengan cangkul pada baris tanaman, sehingga biochar tercampur sempurna dengan tanah pada baris tanaman. Selanjutnya lahan dibiarkan selama 7 hari sebelum ditanami jagung, hal ini dimaksudkan agar biochar yang diaplikasikan sudah berikatan dengan tanah sehingga tidak mudah terbawa aliran permukaan.

\subsubsection{Penanaman jagung}

Penanaman jagung dilakukan 7 hari setelah aplikasi biochar. Hal ini dimaksudkan agar biochar yang diaplikasikan sudah bereaksi dengan tanah. Penanaman dilakukan dengan menggunakan ukuran jarak tanam $25 \mathrm{~cm}$ x $75 \mathrm{~cm}$. Penanaman jagung dilakukan dengan menggunakan tugal dengan jumlah 1 benih per lubang. Penyulaman dilakukan 7 hari setelah tanam apabila ada benih yang tidak tumbuh atau terlihat benih terkena penyakit.

\subsubsection{Pemupukan tanaman}

Penelitian ini menggunakan pupuk Urea, TSP dan KCl. Pemupukan TSP diberikan sekaligus seminggu setelah tanam dengan dosis sesuai perlakuan yaitu $0 \mathrm{~kg} \mathrm{ha}^{-1}(\mathrm{P} 0), 80 \mathrm{~kg} \mathrm{ha}^{-1}(\mathrm{P} 1)$, dan $160 \mathrm{~kg} \mathrm{ha}^{-1}(\mathrm{P} 2)$. Pupuk Urea diberikan dengan dosis
$350 \mathrm{~kg} \mathrm{ha}^{-1}$ dengan 3 tahap pemupukan. Pemupukan pertama dilakukan pada 7 hari setelah tanam dengan dosis sebesar $100 \mathrm{~kg} \mathrm{ha}^{-1}$, pemupukan kedua dilakukan pada 28 hari setelah tanam dengan dosis sebesar $150 \mathrm{~kg} \mathrm{ha}^{-1}$, dan pemupukan ketiga diberikan pada umur tanaman 40 hari setelah tanam dengan dosis sebesar $100 \mathrm{~kg} \mathrm{ha}^{-1}$. Pupuk $\mathrm{KCl}$ dengan dosis $100 \mathrm{~kg} \mathrm{ha}^{-1}$ diberikan dalam 2 tahap pemberian. Pemupukan $\mathrm{KCl}$ pertama diberikan pada umur tanaman 7 hari setelah tanam dengan dosis sebesar $50 \mathrm{~kg} \mathrm{ha}^{-1}$ dan pemupukan kedua diberikan pada umur tanaman 28 hari setelah tanam dengan dosis sebesar $50 \mathrm{~kg} \mathrm{ha}^{-1}$. Pengaplikasi-an pupuk dicampur secara merata terlebih dahulu dan diaplikasikan dengan cara ditugal pada baris tanaman dengan jarak $5 \mathrm{~cm}$ dari lubang tanam.

\subsubsection{Pemeliharaan tanaman}

Pemeliharaan pada tanaman ini berupa penyiraman, penyiangan, dan pengendalian OPT. Penyiraman dilakukan dua kali setiap harinya. Penyiangan terhadap gulma dilakukan dengan manual yaitu dicabut atau dibabat kemudian dibakar di tempat yang telah disediakan serta dilakukan juga penyemprotan herbisida kontak Gramaxone 275SL dengan dosis 2 liter per ha ${ }^{-1}$. Pengendalian OPT dilakukan sesuai dengan kondisi serangan dengan menggunakan pestisida, dan tanaman yang terkena penyakit akan dilakukan seleksi kemudian dibakar.

\subsubsection{Panen}

Panen jagung dilakukan apabila sebagian besar kelobot pada pertanaman mulai kering berwarna kuning yaitu 90 hari setelah tanam. Panen dilakukan dengan cara manual yaitu memetik tongkol jagung.

\subsubsection{Pengambilan Sampel Tanah}

Pengambilan sampel tanah dilakukan sebelum pengaplikasian biochar dan setelah panen dengan menggunakan alat bor tanah. Sampel tanah diambil secara komposit di 5 titik sedalam $0-20 \mathrm{~cm}$ per ulangan.

\subsection{Pelaksanaan Laboratorium}

\subsubsection{Analisis Tanah}

Analisis tanah dilakukan pada contoh tanah sebelum tanam dan sesudah panen Analisis yang 
dilakukan meliputi : N-total dengan menggunakan metode Kjehdahl, K-dd dengan menggunakan metode pengekstrak ammonium asetat (NH4OAc) $\mathrm{pH}$ 7, KTK tanah dengan menggunakan metode ammonium asetat (NH4OAc) $\mathrm{pH} \mathrm{7,} \mathrm{C-organik}$ dengan menggunakan metode Walkey and Black. Selanjutnya data disajikan dengan menggunakan kurva untuk membandingkan sifat kimia tanah berdasarkan perlakuan yang diberikan.

\section{HASIL DAN PEMBAHASAN}

\subsection{N-total Tanah}

Hasil penelitian menunjukan bahwa kombinasi pemberian biochar batang singkong dan pemupukan $\mathrm{P}$ dapat meningkatkan kadar N-total tanah. Pengaruh pemberian biochar dan pemupukan P terhadap kadar N-total tanah dapat dilihat pada Gambar 1. Gambar tersebut menunjukkan bahwa kadar N-total tertinggi terdapat pada perlakuan B2P1 yaitu kombinasi pemberian biochar batang singkong 5 ton ha $\mathrm{ha}^{-1} \mathrm{dan}$ pemupukan P2O5 $36 \mathrm{~kg} \mathrm{ha}^{-1}$ (80 $\mathrm{kg} \mathrm{ha}^{-1} \mathrm{TSP}$ ), sedangkan kadar N-total terendah pada perlakuan kontrol B0P0 yaitu tanpa pemberian biochar batang singkong dan pemupukan $P$.

Pengaruh pemberian biochar batang singkong terhadap kadar N-total pada tanah Ultisol dapat dilihat pada Gambar 2 yang memperlihatkan bahwa peningkatan dosis pemberian biochar batang singkong mampu meningkatkan kadar N-total pada tanah. Pada perlakuan tanpa biochar (kontrol) kadar N- total tanah sebesar $0,17 \%$, meningkat menjadi $0,20 \%$ pada perlakuan pemberian biochar 2,5 ton ha $\mathrm{h}^{-1}$ (B1), dan kadar N-total tertinggi yaitu pada perlakuan biochar 5 ton ha ${ }^{-1}$ (B2) sebesar $0,27 \%$.

Pengaruh pemupukan $\mathrm{P}$ terhadap kadar $\mathrm{N}$-total pada tanah Ultisol dapat dilihat pada Gambar 3. Gambar tersebut menunjukan bahwa pemupukan P mampu meningkatkan kadar N-total pada tanah Ultisol. Pada perlakuan tanpa pemupukan $\mathrm{P}$ (kontrol) kadar N-total tanah sebesar 0,2\%, kadar $\mathrm{N}$-total meningkat menjadi $0,22 \%$ pada perlakuan pemupukan P2O5 $36 \mathrm{~kg} \mathrm{ha}^{-1}$ (80 $\mathrm{kg} \mathrm{ha}^{-1} \mathrm{TSP}$ ) (P1) tetapi relatif tidak berbeda dengan perlakuan pemupukan P2O5 $72 \mathrm{~kg} \mathrm{ha}^{-1}$ (160 $\mathrm{kg} \mathrm{ha}^{-1} \mathrm{TSP}$ ) (P2) kadar N-total sebesar 0,22\%.

\subsection{K-dd Tanah}

Hasil penelitian menunjukan bahwa kombinasi pemberian biochar batang singkong dan pemupukan P mampu meningkatkan kadar K-dd tanah. Pengaruh pemberian biochar batang singkong dan pemupukan P terhadap kadar K-dd tanah dapat dilihat pada Gambar 4. Gambar tersebut menunjukkan bahwa kadar K-dd tanah tertinggi

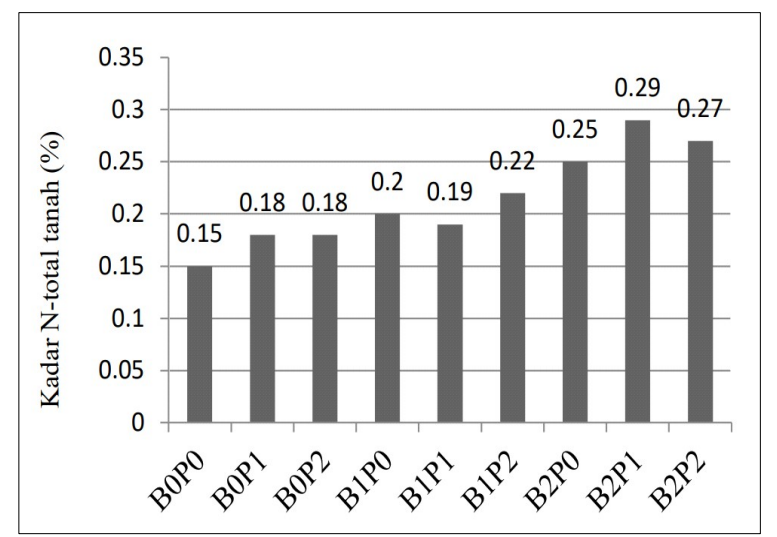

Gambar 1. Hasil kadar N-total tanah Ultisol pada penelitian pemberian biochar batang singkong dan pemupukan $\mathrm{P}$.

Keterangan: B0P0: Biochar 0 ton $\mathrm{ha}^{-1}+$ pemupukan $\mathrm{P} 2 \mathrm{O} 5$ $0 \mathrm{~kg} \mathrm{ha}{ }^{-1}$, B0P1: Biochar 0 ton ha- ${ }^{-1}+$ pemupukan $\mathrm{P} 2 \mathrm{O} 536 \mathrm{~kg} \mathrm{ha}^{-1}$ (80 kg ha-1 TSP), B0P2: Biochar 0 ton $\mathrm{ha}^{-1}+$ pemupukan $\mathrm{P} 2 \mathrm{O} 5$ $72 \mathrm{~kg} \mathrm{ha}^{-1}$ (160 kg ha-1 TSP), B1P0: Biochar 2,5 ton $\mathrm{ha}^{-1}+$ pemupukan P2O5 $0 \mathrm{~kg} \mathrm{ha}^{-1}$, B1P1: Biochar 2,5 ton ha-1 + pemupukan P2O5 $36 \mathrm{~kg} \mathrm{ha}^{-1}$ (80 $\mathrm{kg} \mathrm{ha}^{-1}$ TSP), B1P2: Biochar 2,5 ton ha ${ }^{-1}+$ pemupukan P2O5 72 $\mathrm{kg} \mathrm{ha}^{-1}$ (160 kg ha-1 TSP), B2P0: Biochar 5 ton ha ${ }^{-1}+$ pemupukan P2O5 $0 \mathrm{~kg} \mathrm{ha}^{-1}$, B2P1: Biochar 5 ton $\mathrm{ha}^{-1}+$ pemupukan $\mathrm{P} 2 \mathrm{O} 536 \mathrm{~kg}$ $\mathrm{ha}^{-1}$ (80 $\mathrm{kg} \mathrm{ha}^{-1}$ TSP), B2P2: Biochar 5 ton $\mathrm{ha}^{-1}+$ pemupukan P2O5 $72 \mathrm{~kg} \mathrm{ha}^{-1}(160 \mathrm{~kg}$ ha' ${ }^{-1}$ TSP).

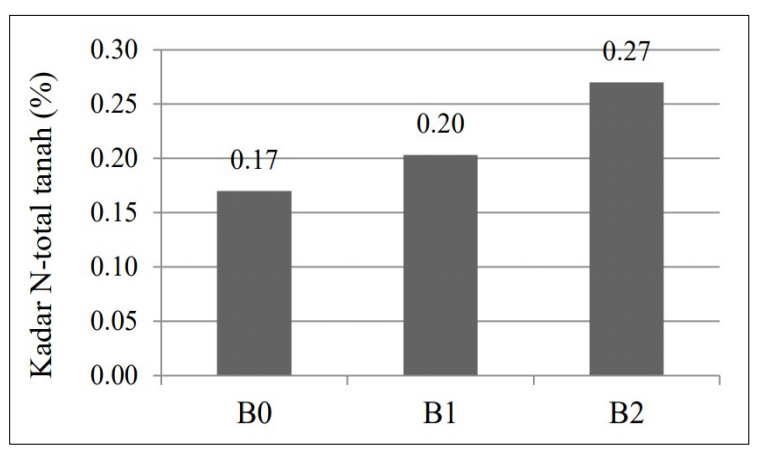

Gambar 2. Pengaruh Pemberian Biochar Batang Singkong terhadap Kadar N-Total Tanah Ultisol.

Keterangan: B0: Biochar 0 ton $\mathrm{ha}^{-1}$, B1: Biochar 2,5 ton $\mathrm{ha}^{-1}, \mathrm{~B} 2$ : Biochar 5 ton ha-1. 
terdapat pada perlakuan $\mathrm{B} 2 \mathrm{P} 1$ yaitu kombinasi perlakuan biochar 5 ton ha ${ }^{-1}$ dan pemupukan $\mathrm{P} 2 \mathrm{O} 5$ $36 \mathrm{~kg} \mathrm{ha}^{-1}$ (80 kg ha-1 TSP), sedangkan kadar Kdd terendah pada perlakuan kontrol yaitu kombinasi perlakuan tanpa pemberian biochar dan pemupukan $\mathrm{P}$ (B0P0).

Hasil penelitian menunjukan bahwa peningkatan pemberian dosis biochar meningkatkan kadar Kdd pada tanah Ultisol yang dapat dilihat pada Gambar 5. Peningkatan dosis pemberian biochar batang singkong mampu meningkatkan kadar Kdd pada tanah. Pada perlakuan tanpa biochar (kontrol) kadar K-dd sebesar 0,28 $\mathrm{cmol}^{(+)} \mathrm{kg}^{-1}$, meningkat menjadi $0,35 \mathrm{cmol}^{(+)} \mathrm{kg}^{-1}$ pada B1 pemberian biochar 2,5 ton ha-1, dan kadar K-dd tertinggi yaitu pada $\mathrm{B} 2$ dengan pemberian biochar 5 ton ha- ${ }^{-1}$ sebesar $0,54 \mathrm{cmol}^{(+)} \mathrm{kg}^{-1}$.

Hasil penelitian menunjukan bahwa peningkatan dosis pemupukan P meningkatkan kadar K-dd pada tanah Ultisol yang dapat dilihat pada Gambar 6 . Pada Gambar 6 menunjukan bahwa pemupukan P mampu meningkatkan kadar K-dd pada tanah Ultisol. Pada perlakuan tanpa pemupukan $\mathrm{P}$ (kontrol) kadar K-dd tanah sebesar $0,33 \mathrm{cmol}^{(+)} \mathrm{kg}^{-1}$, kadar K-dd meningkat menjadi $0,4 \mathrm{cmol}(+) \mathrm{kg}^{-1}$ pada perlakuan pemupukan P2O5 $36 \mathrm{~kg} \mathrm{ha}^{-1}\left(80 \mathrm{~kg} \mathrm{ha}^{-1}\right.$ TSP)(P1) tetapi relatif tidak berbeda dengan perlakuan pemupukan P2O5 $72 \mathrm{~kg} \mathrm{ha}^{-1}$ (160 kg ha-1 TSP) (P2) kadar K-dd sebesar 0,43 cmol (+) $\mathrm{kg}^{-1}$.

\subsection{KTK Tanah}

Hasil penelitian menunjukan bahwa kombinasi pemberian biochar batang singkong dan pemupukan $P$ dapat meningkatkan KTK tanah. Pengaruh pemberian biochar batang singkong dan

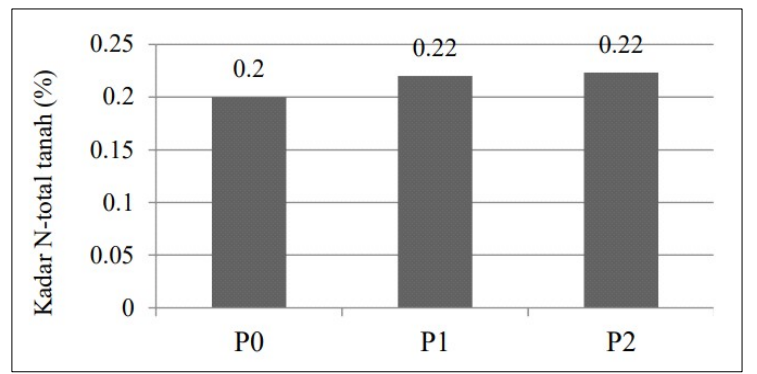

Gambar 3. Pengaruh Pemupukan P terhadap Kadar N-Total Tanah Ultisol.

Keterangan: P0: pemupukan $\mathrm{P}_{2} \mathrm{O}_{5} 0 \mathrm{~kg} \mathrm{ha}^{-1}, \mathrm{P}$ : pemupukan $\mathrm{P}_{2} \mathrm{O}_{5} 36 \mathrm{~kg} \mathrm{ha}^{-1}\left(80 \mathrm{~kg} \mathrm{ha}^{-1}\right.$ TSP), $\mathrm{P} 2$ : pemupukan $\mathrm{P}_{2} \mathrm{O}_{5} 72 \mathrm{~kg} \mathrm{ha}^{-1}$ (160 $\mathrm{kg} \mathrm{ha}^{-1}$ TSP). pemupukan P terhadap KTK tanah dapat dilihat pada Gambar 7. Gambar tersebut menunjukan KTK tertinggi pada perlakuan $\mathrm{B} 2 \mathrm{P} 2$ yaitu perlakuan pemberian biochar 5 ton ha $^{-1}$ dan pemupukan

P O $72 \mathrm{~kg} \mathrm{ha}^{-1}$ (160 kg ha-1 TSP), sedangkan kadar KTK terendah pada perlakuan B0P0 (kontrol) yaitu perlakuan tanpa pemberian biochar batang singkong dan pemupukan P.

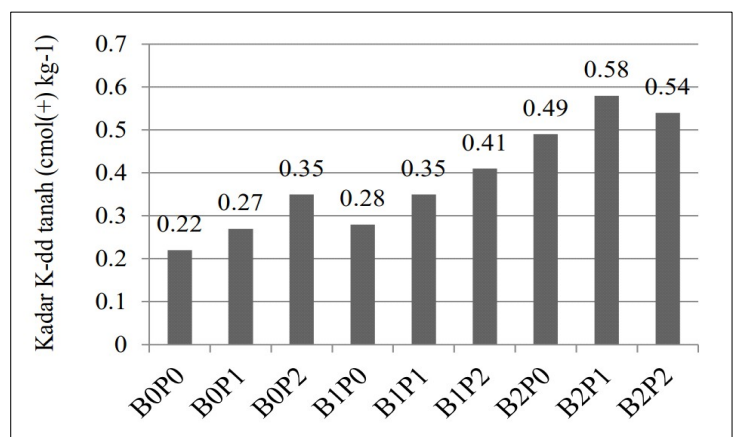

Gambar 4. Hasil Kadar K-dd Tanah Ultisol pada Penelitian Pemberian Biochar Batang Singkong dan Pemupukan P

Keterangan: B0P0: Biochar 0 ton $\mathrm{ha}^{-1}+$ pemupukan $\mathrm{P} 2 \mathrm{O} 5$ $0 \mathrm{~kg} \mathrm{ha}{ }^{-1}$, B0P1: Biochar 0 ton ha ${ }^{-1}+$ pemupukan $\mathrm{P} 2 \mathrm{O} 536 \mathrm{~kg} \mathrm{ha}^{-1}$ (80 kg ha-1 TSP), B0P2: Biochar 0 ton ha $^{-1}+$ pemupukan P2O5 $72 \mathrm{~kg} \mathrm{ha}^{-1}$ (160 kg ha-1 TSP), B1P0: Biochar 2,5 ton $\mathrm{ha}^{-1}+$ pemupukan P2O5 $0 \mathrm{~kg} \mathrm{ha}^{-1}$, B1P1: Biochar 2,5 ton ha-1 + pemupukan P2O5 $36 \mathrm{~kg} \mathrm{ha}^{-1}$ (80 $\mathrm{kg} \mathrm{ha}^{-1}$ TSP), B1P2: Biochar 2,5 ton ha-1 + pemupukan P2O5 72 $\mathrm{kg} \mathrm{ha}^{-1}$ (160 kg ha-1 TSP), B2P0: Biochar 5 ton ha ${ }^{-1}+$ pemupukan P2O5 $0 \mathrm{~kg} \mathrm{ha}^{-1}$, B2P1: Biochar 5 ton $\mathrm{ha}^{-1}+$ pemupukan P2O5 $36 \mathrm{~kg}$ $\mathrm{ha}^{-1}$ (80 kg ha-1 TSP), B2P2: Biochar 5 ton $\mathrm{ha}^{-1}+$ pemupukan P2O5 $72 \mathrm{~kg} \mathrm{ha}^{-1}(160 \mathrm{~kg}$ $\mathrm{ha}^{-1}$ TSP).

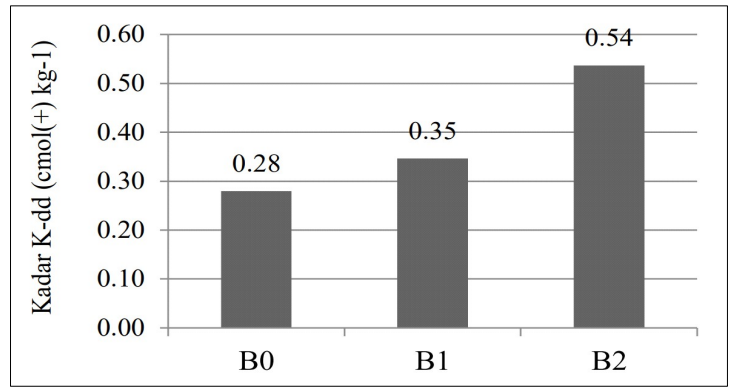

Gambar 5. Pengaruh Pemberian Biochar Batang Singkong terhadap Kadar K-dd Tanah Ultisol.

Keterangan: B0: Biochar 0 ton ha ${ }^{-1}$, B1: Biochar 2,5 ton $\mathrm{ha}^{-1}, \mathrm{~B} 2$ : Biochar 5 ton ha ${ }^{-1}$. 


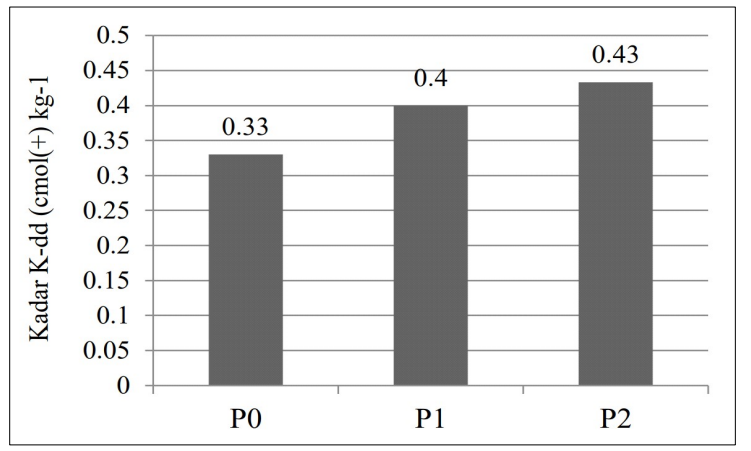

Gambar 6. Pengaruh Pemupukan P terhadap Kadar K-dd Tanah Ultisol.

Keterangan: P0: pemupukan $\mathrm{P}_{2} \mathrm{O}_{5} 0 \mathrm{~kg} \mathrm{ha}^{-1}, \mathrm{P} 1$ : pemupukan $\mathrm{P}_{2} \mathrm{O}_{5} 36 \mathrm{~kg} \mathrm{ha}^{-1}\left(80 \mathrm{~kg} \mathrm{ha}^{-1}\right.$ TSP), $\mathrm{P} 2$ : pemupukan $\mathrm{P}_{2} \mathrm{O}_{5} 72 \mathrm{~kg} \mathrm{ha}^{-1}$ (160 $\mathrm{kg} \mathrm{ha}^{-1}$ TSP).

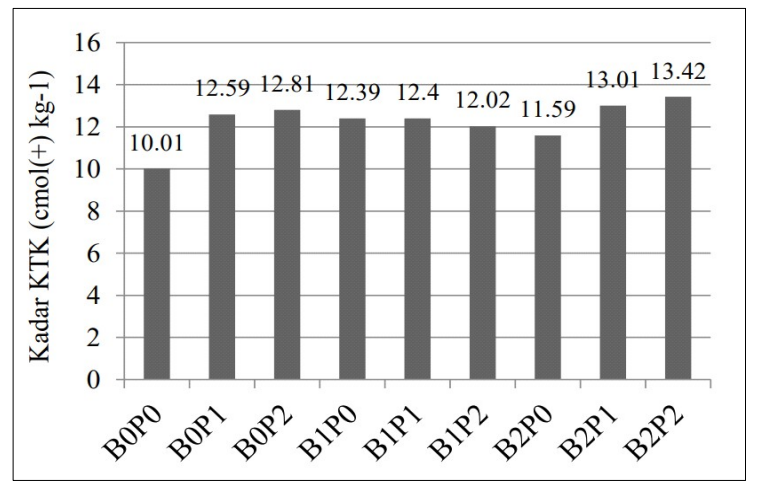

Gambar 7. Hasil KTK Tanah Ultisol pada Penelitian Pemberian Biochar Batang Singkong dan Pemupukan P.

Keterangan: B0P0: Biochar 0 ton ha ${ }^{-1}+$ pemupukan $\mathrm{P} 2 \mathrm{O} 5$ $0 \mathrm{~kg} \mathrm{ha}^{-1}$, B0P1: Biochar 0 ton ha ${ }^{-1}+$ pemupukan $\mathrm{P} 2 \mathrm{O} 536 \mathrm{~kg} \mathrm{ha}^{-1}$ (80 kg ha-1 TSP), B0P2: Biochar 0 ton ha ${ }^{-1}+$ pemupukan P2O5 $72 \mathrm{~kg} \mathrm{ha}^{-1}$ (160 $\left.\mathrm{kg} \mathrm{ha}^{-1} \mathrm{TSP}\right)$, B1P0: Biochar 2,5 ton ha ${ }^{-1}+$ pemupukan P2O5 $0 \mathrm{~kg} \mathrm{ha}^{-1}$, B1P1: Biochar 2,5 ton ha ${ }^{-1}+$ pemupukan P2O5 $36 \mathrm{~kg} \mathrm{ha}^{-1}$ (80 kg ha-1 TSP), B1P2: Biochar 2,5 ton ha ${ }^{-1}+$ pemupukan P2O5 72 $\mathrm{kg} \mathrm{ha}^{-1}$ (160 kg ha-1 TSP), B2P0: Biochar 5 ton ha ${ }^{-1}+$ pemupukan P2O5 $0 \mathrm{~kg} \mathrm{ha}^{-1}$, B2P1: Biochar 5 ton ha- ${ }^{-1}+$ pemupukan P2O5 $36 \mathrm{~kg}$ $\mathrm{ha}^{-1}$ (80 kg ha-1 TSP), B2P2: Biochar 5 ton ha $^{-1}+$ pemupukan P2O5 $72 \mathrm{~kg} \mathrm{ha}^{-1}(160 \mathrm{~kg}$ ha ${ }^{-1}$ TSP).

Hasil dari penelitian ini juga menunjukan bahwa peningkatan dosis pemberian biochar batang singkong mampu meningkatkan KTK di dalam tanah Ultisol Gambar 8. Gambar tersebut menunjukkan bahwa peningkatan pemberian dosis biochar dapat meningkatan KTK di dalam tanah. Pada perlakuan kontrol (B0) KTK tanah sebesar $11,80 \mathrm{cmol}(+) \mathrm{kg}^{-1}$, terjadi peningkatan pada perlakuan biochar 2,5 ton ha-1 (B1) sebesar 12,27 $\mathrm{cmol}(+) \mathrm{kg}^{-1}$, relatif tidak berbeda dengan perlakuan pemberian biochar 5 ton ha-1 (B2) sebesar 12,67 cmol (+) $\mathrm{kg}^{-1}$.

Hasil dari penelitian ini menunjukan bahwa peningkatan dosis pemupukan $\mathrm{P}$ dapat meningkatkan KTK pada tanah Ultisol yang dapat dilihat pada Gambar 9. Pada Gambar tersebut dapat dilihat pengaruh pemupukan P terhadap KTK pada tanah Ultisol. KTK terendah didapat pada perlakuan (P0) kontrol pemupukan P2O5 $0 \mathrm{~kg} \mathrm{ha}^{-}$ ${ }^{1}$ sebesar $11,33 \mathrm{cmol}(+) \mathrm{kg}^{-1}$, selanjutnya pada perlakuan (P1) pemupukan P2O5 $36 \mathrm{~kg} \mathrm{ha}^{-1}(80 \mathrm{~kg}$ $\mathrm{ha}^{-1}$ TSP) hasil KTK tanah meningkat menjadi $12,67 \mathrm{cmol}(+) \mathrm{kg}^{-1}$, yang relatif tidak berbeda dengan perlakuan (P2) pemupukan $\mathrm{P} 2 \mathrm{O} 572 \mathrm{~kg}$ $\mathrm{ha}^{-1}$ (160 kg ha ${ }^{-1}$ TSP) yang meningkat sebesar $12,75 \mathrm{cmol}(+) \mathrm{kg}^{-1}$.

\subsection{C-organik Tanah}

Hasil penelitian menunjukan bahwa kombinasi pemberian biochar batang singkong dan pemupukan $\mathrm{P}$ dapat meningkatkan kadar C-organik di dalam tanah. Pengaruh pemberian biochar batang singkong dan pemupukan $\mathrm{P}$ terhadap kadar C-organik dapat dilihat pada Gambar 10. Gambar 10 dapat dilihat bahwa kadar $\mathrm{C}$ - organik tertinggi pada perlakuan B2P1 yaitu pemberian biochar 5 ton ha ${ }^{-1}$ dan pemupukan P2O5 $36 \mathrm{~kg} \mathrm{ha}^{-1}\left(80 \mathrm{~kg} \mathrm{ha}^{-1}\right.$ TSP) sebesar 2,94\%, sedangkan kadar K-dd terendah pada perlakuan B0P0 (kontrol) sebesar 1,92\%.

Hasil dari penelitian ini menunjukan bahwa pemberian Biochar batang singkong dapat meningkatkan kadar C-organik pada tanah Ultisol yang dapat dilihat pada Gambar 11. Gambar 11 memperlihatkan bahwa peningkatan dosis pemberian biochar batang singkong mampu meningkatkan C-organik pada tanah. Pada perlakuan tanpa biochar (kontrol) kadar C-organik sebesar $2,00 \%$, meningkat menjadi $2,47 \%$ pada pemberianbiochar 2,5 ton ha-1(B1), kadar Corganik tertinggi yaitu pada pemberian biochar 5 ton ha $^{-1}$ (B2) sebesar $2,85 \%$.

Hasil dari penelitian ini menunjukan bahwa pemupukan $\mathrm{P}$ dapat meningkatkan $\mathrm{C}$ - organik pada tanah Ultisol yang dapat dilihat pada Gambar 12. Gambar 12 memperlihatkan bahwa pemupukan P dapat meningkatkan kadar C- organik pada tanah ultisol. Kadar C-organik tertinggi terdapat pada 


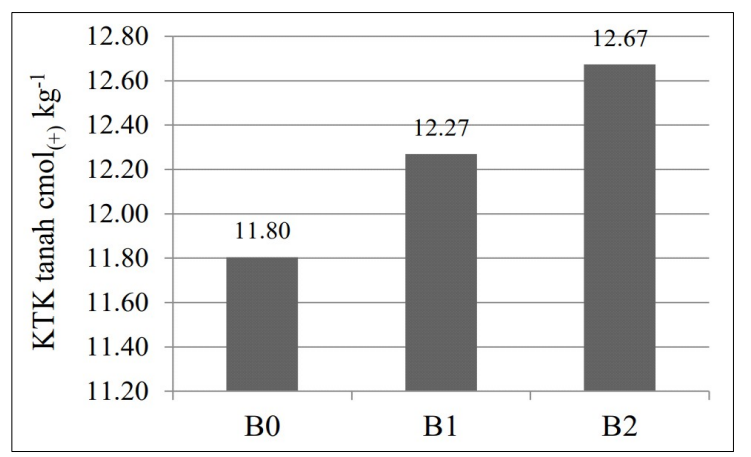

Gambar 8. Pengaruh Pemberian Biochar Batang Singkong terhadap KTK Tanah Ultisol.

Keterangan: B0: Biochar 0 ton ha ${ }^{-1}$, B1: Biochar 2,5 ton ha- ${ }^{-1}$, B2: Biochar 5 ton ha-1 .

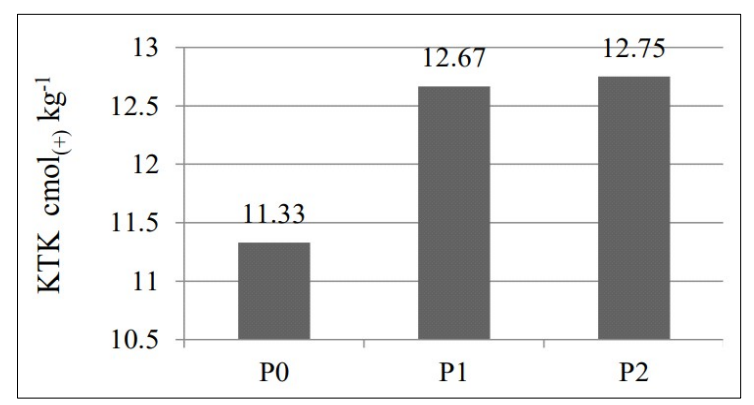

Gambar 9. Pengaruh Pemupukan P terhadap KTK Tanah Ultisol.

Keterangan: P0: pemupukan $\mathrm{P}_{2} \mathrm{O}_{5} 0 \mathrm{~kg} \mathrm{ha}^{-1}, \mathrm{P} 1$ : pemupukan $\mathrm{P}_{2} \mathrm{O}_{5} 36 \mathrm{~kg} \mathrm{ha}^{-1}\left(80 \mathrm{~kg} \mathrm{ha}^{-1}\right.$ TSP), $\mathrm{P} 2$ : pemupukan $\mathrm{P}_{2} \mathrm{O}_{5} 72 \mathrm{~kg} \mathrm{ha}^{-1}$ (160 $\left.\mathrm{kg} \mathrm{ha}^{-1} \mathrm{TSP}\right)$.

perlakuan (P1) pemupukan P2O5 $36 \mathrm{~kg} \mathrm{ha}^{-1}(80$ $\mathrm{kg} \mathrm{ha}^{-1} \mathrm{TSP}$ ) sebesar 2,53\%, kadar C-organik relatif tidak berbeda dengan perlakuan (P2) pemupukan P2O5 $72 \mathrm{~kg} \mathrm{ha}^{-1}$ (160 $\left.\mathrm{kg} \mathrm{ha}^{-1} \mathrm{TSP}\right)$ sebesar 2,5\%, sedangkan kadar C-organik terendah terdapat pada perlakuan kontrol (P0) pemupukan $\mathrm{P} 2 \mathrm{O} 50 \mathrm{~kg}$ ha${ }^{1}$ yaitu sebesar $2,29 \%$.

\subsection{Pembahasan}

Kombinasi perlakuan pemberian biochar batang singkong dan pemupukan $\mathrm{P}$ mampu meningkatkan kadar N-total tanah dapat dilihat pada Gambar 1. Kadar N-total tertinggi yaitu pada perlakuan pemberian biochar batang singkong 5 ton ha ${ }^{-1}$ dan pemupukan P2O5 $36 \mathrm{~kg} \mathrm{ha}^{-1}$ (B2P1) sebesar $0,29 \%$ (sedang), kadar N-total ini lebih besar dibandingkan perlakuan kontrol (B0P0) yaitu sebesar $0,15 \%$ (rendah). Peningkatan dosis pemberian biochar batang singkong mampu meningkatkan kadar N-total tanah Gambar 2. Hal ini dikarenakan permukaan oksidasi pada biochar efektif menjerap $\mathrm{NH} 4+$ yang berasal dari perlakuan terdapat pupuk urea sehingga dapat berpotensi meningkatkan kadar $\mathrm{N}$-total tanah dan mengurangi kehilangan $\mathrm{N}$ akibat pencucian. Hal ini sejalan dengan penelitian Lehmann et al. (2007) yang menyatakan bahwa pemberian biochar nyata meningkatkan ketersedian hara di tanah, salah satunya nitrogen karena pencucian hara $\mathrm{N}$ berkurang nyata dengan adanya pemberian biochar. Penelitian Hale et al. (2013) membuktikan bahwa biochar mampu meretensi $\mathrm{N}$ dan $\mathrm{P}$ sehingga tidak mudah hanyut terbawa air dan akan tersedia bagi tanaman, karena biochar memiliki kapasitas menahan air yang tinggi, sehingga dapat menjaga unsur hara $\mathrm{N}$ agar tidak mudah tercuci dan menjadikannya lebih tersedia untuk tanaman.

Pemberian kombinasi biochar batang singkong dan pemupukan $\mathrm{P}$ ke dalam tanah memperlihatkan berbagai macam keuntungan dalam kaitan memperbaiki kualitas tanah, salah satunya meningkatkan ketersediaan hara $\mathrm{K}$ di tanah. Hal ini dibuktikan dengan hasil penelitian bahwa kombinasi pemberian biochar batang singkong dan pemupukan $\mathrm{P}$ dapat meningkatkan kadar K-dd dibandingkan dengan kontrol (Gambar 4). Dari gambar tersebut dapat dijelaskan bahwa perlakuan kontrol (B0P0) memiliki kadar K-dd terendah sebesar $0,22 \mathrm{cmol}(+) \mathrm{kg}^{-1}$ (rendah) dan kadar Kdd tertinggi terdapat pada perlakuan pemberian biochar batang singkong 5 ton ha ${ }^{-1}$ dan pemupukan P2O5 $36 \mathrm{~kg} \mathrm{ha}^{-1}(\mathrm{~B} 2 \mathrm{P} 1)$ sebesar $0,58 \mathrm{cmol}(+) \mathrm{kg}^{-}$ ${ }^{1}$ (sedang). Peningkatan dosis pemberian biochar batang singkong dapat meningkatkan kadar K-dd pada tanah Ultisol yang dapat dilihat pada gambar 6. Hal ini disebabkan salah satu peranan biochar dalam tanah adalah sebagai sumber bahan organik yang mampu meningkatkan ketersediaan hara dalam tanah (Lehman dan Joseph, 2009). Hasil penelitian Widowati (2010) dan Widowati et al. (2012) juga menyatakan bahwa pemberian biochar menghasilkan kejenuhan basa dan kadar $\mathrm{K}$ tanah yang lebih tinggi dari kontrol. Biochar juga mempunyai kemampuan untuk mengikat $\mathrm{K}$ sehingga menurunkan potensi pencucian hara $\mathrm{K}$ sehingga meningkatkan K-dd tanah.

Hasil dari penelitian ini menunjukan bahwa pemberian biochar dan pemupukan $\mathrm{P}$ mampu meningkatkan KTK tanah Gambar 7. Liang et al. (2006) menyatakan bahwa terdapat dua 


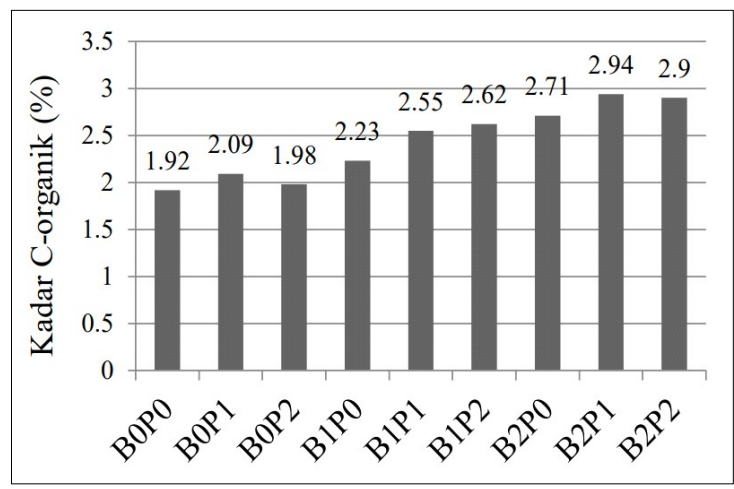

Gambar 10. Hasil Kadar C-organik Tanah Ultisol pada Penelitian Pemberian Biochar Batang Singkong dan Pemupukan P.

Keterangan: B0P0: Biochar 0 ton $\mathrm{ha}^{-1}+$ pemupukan $\mathrm{P} 2 \mathrm{O} 5$ $0 \mathrm{~kg} \mathrm{ha}{ }^{-1}$, B0P1: Biochar 0 ton ha-1 + pemupukan $\mathrm{P} 2 \mathrm{O} 536 \mathrm{~kg} \mathrm{ha}^{-1}$ (80 kg ha-1 TSP), B0P2: Biochar 0 ton ha $^{-1}+$ pemupukan P2O5 $72 \mathrm{~kg} \mathrm{ha}^{-1}$ (160 kg ha ${ }^{-1}$ TSP), B1P0: Biochar 2,5 ton ha- $\mathrm{h}^{-1}$ pemupukan P2O5 $0 \mathrm{~kg} \mathrm{ha}^{-1}$, B1P1: Biochar 2,5 ton ha ${ }^{-1}+$ pemupukan P2O5 $36 \mathrm{~kg} \mathrm{ha}^{-1}$ (80 $\mathrm{kg} \mathrm{ha}^{-1}$ TSP), B1P2: Biochar 2,5 ton ha-1 + pemupukan P2O5 72 $\mathrm{kg} \mathrm{ha}^{-1}$ (160 kg ha ${ }^{-1}$ TSP), B2P0: Biochar 5 ton ha ${ }^{-1}+$ pemupukan $\mathrm{P} 2 \mathrm{O} 50 \mathrm{~kg} \mathrm{ha}^{-1}$, B2P1: Biochar 5 ton ha ${ }^{-1}+$ pemupukan P2O5 $36 \mathrm{~kg}$ $\mathrm{ha}^{-1}$ (80 kg ha $\mathrm{kSP}^{-1}$ ), B2P2: Biochar 5 ton $\mathrm{ha}^{-1}+$ pemupukan P2O5 $72 \mathrm{~kg} \mathrm{ha}^{-1}(160 \mathrm{~kg}$ ha ${ }^{-1}$ TSP).

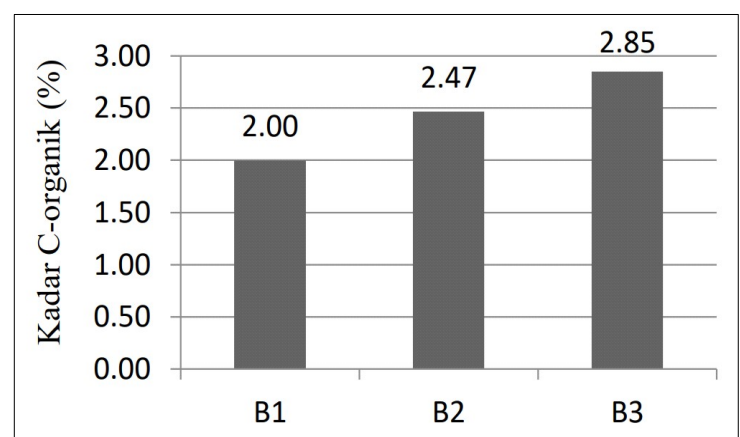

Gambar 11. Pengaruh Pemberian Biochar Batang Singkong terhadap Kadar C-organik Tanah Ultisol.

Keterangan: $\mathrm{B} 0$ : Biochar 0 ton $\mathrm{ha}^{-1}, \mathrm{~B} 1$ : Biochar 2,5 ton ha $^{-1}$, B2: Biochar 5 ton ha-1.

mekanisme yang menyebabkan terjadinya peningkatan nilai kapasitas tukar kation (KTK) tanah setelah penambahan biochar yaitu (a) adanya luas permukaan yang lebih tinggi pada biochar untuk menjerap kation-kation. (b) adanya

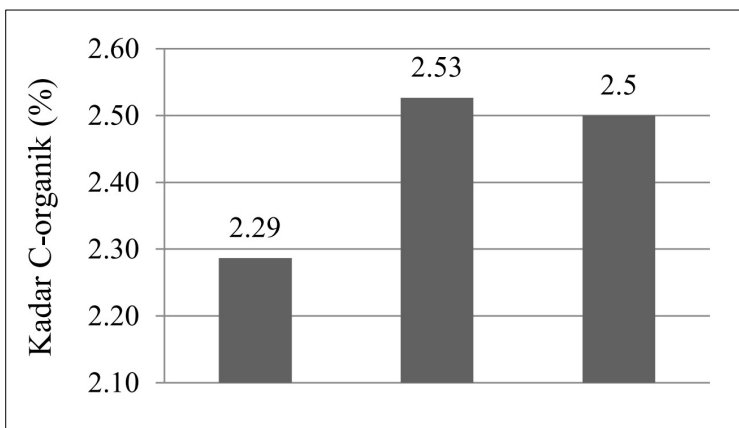

Gambar 12. Pengaruh Pemupukan P terhadap Kadar C-organik Tanah Ultisol.

Keterangan: $\mathrm{B} 0 \mathrm{P} 0$ : Biochar 0 ton ha-1 ${ }^{-1}$ pemupukan $\mathrm{P} 2 \mathrm{O} 5$ $0 \mathrm{~kg} \mathrm{ha}^{-1}$, B0P1: Biochar 0 ton ha ${ }^{-1}+$ pemupukan P2O5 $36 \mathrm{~kg} \mathrm{ha}^{-1}$ (80 kg ha-1 TSP), B0P2: Biochar 0 ton ha'- + pemupukan P2O5 $72 \mathrm{~kg} \mathrm{ha}^{-1}$ (160 $\left.\mathrm{kg} \mathrm{ha}^{-1} \mathrm{TSP}\right)$, B1P0: Biochar 2,5 ton ha ${ }^{-1}+$ pemupukan P2O5 $0 \mathrm{~kg} \mathrm{ha}^{-1}$, B1P1: Biochar 2,5 ton ha-1 + pemupukan P2O5 $36 \mathrm{~kg} \mathrm{ha}^{-1}$ (80 $\mathrm{kg} \mathrm{ha}^{-1}$ TSP), B1P2: Biochar 2,5 ton ha $\mathrm{a}^{-1}+$ pemupukan P2O5 72 $\mathrm{kg} \mathrm{ha}^{-1}\left(160 \mathrm{~kg} \mathrm{ha}^{-1} \mathrm{TSP}\right), \mathrm{B} 2 \mathrm{P0}$ : Biochar 5 ton ha ${ }^{-1}+$ pemupukan P2O5 $0 \mathrm{~kg} \mathrm{ha}^{-1}, \mathrm{~B} 2 \mathrm{P} 1$ : Biochar 5 ton ha ${ }^{-1}+$ pemupukan P2O5 $36 \mathrm{~kg}$ $\mathrm{ha}^{-1}$ (80 $\mathrm{kg} \mathrm{ha}^{-1}$ TSP), B2P2: Biochar 5 ton $\mathrm{ha}^{-1}+$ pemupukan P2O5 $72 \mathrm{~kg} \mathrm{ha}^{-1}(160 \mathrm{~kg}$ ha $^{-1}$ TSP).

kepadatan muatan yang lebih tinggi pada biochar. Adanya pori mikro pada biochar maka dapat membantu dalam menjerap katio-kation basa seperti $\mathrm{K}^{+}, \mathrm{Ca}^{2+}, \mathrm{Mg}^{2+}$ dan $\mathrm{Na}^{+}$dalam koloid tanah yang pada akhirnya akan meningkatkan nilai kapasitas tukar kation (KTK) tanah. Tambunan et al. (2014) juga menyatakan bahwa keberadaan biochar dalam tanah dapat membentuk muatan negatif dan meningkatkan KTK.

Kombinasi biochar batang singkong dan pemupukan $\mathrm{P}$ mampu meningkatkan kadar $\mathrm{C}$ organik di dalam tanah, pada perlakuan pemberian biochar 2,5 ton ha-1 dan pemupukan P2O5 $36 \mathrm{~kg}$ ha $^{-1}$ (80 kg ha-1 TSP) kadar C-organik 2,94\% meningkat dibandingkan dengan perlakuan lainnya meskipun relatif tidak berbeda sudah menunjuka perbedaan dengan perlakuan kontrol Gambar 10. Peningkatan dosis pemberian biochar batang singkong dapat meningkatkan C-organik tanah Ultisol yang dapat dilihat pada Gambar 11. Menurut Solaiman dan Anwar (2015), biochar dapat mengikat $\mathrm{C}$-organik di tanah sehingga tetap stabil dan tidak mudah terdekomposisi oleh mikroorganisme. Menurut Lehmann et al. (2009) 
menyatakan bahwa pengkayaan karbon tanah melalui pemberian pembenah tanah biochar memberikan pengaruh yang positif terhadap kadar C-organik tanah. Hasil penelitian Fauzi et al. (2015) menjelaskan bahwa bahan organik dari kompos blotong tebu dan kotoran sapi banyak mengandung

C-organik, Semakin tinggi taraf dosis bahan organik yang diberikan maka C-organik manjadi semakin tinggi. Hal ini disebabkan bahan organik lebih mempertimbangkan pengaruhnya terhadap sifat kimia tanah karena mempunyai peranan penting salah satunya mencegah keracunan besi dan aluminium pada tanah yang bereaksi masam serta dapat meningkatkan ketersediaan fosfat di dalam tanah.

\section{KESIMPULAN}

Pemberian biochar batang singkong mampu meningkatkan kadar N-total, kadar K-dd, KTK dan kadar C-organik pada tanah Ultisol. Pemupukan P mampu meningkatkan kadar N-total, kadar K-dd, KTK dan kadar C-organik di dalam tanah Ultisol. Kombinasi Pemberian biochar batang singkong dan pemupukan P mampu meningkatkan kadar Ntotal, kadar K-dd, KTK dan kadar C-organik pada tanah Ultisol.

\section{DAFTAR PUSTAKA}

Fauzi, Kumala,S., dan Purba, M.A. 2015. Pengaruh Pemberian Fosfat Alam dan Bahan Organik pada Tanah Sulfat Masam Potensial Terhadap P-Tersedia Tanah dan Produksi Padi (Oryza sativa L.). Jurnal Online Agroekoteaknologi. 3(3) : 938-948.

Fitriatin, B. N., A. Yuniarti., T. Turmuktini., dan F. K. Ruswandi. 2014. The Effect of Phosphate Solubilizing Microbe Producing Growth Regulators on Soil Phosphate, Growth and Yield of Maize and Fertilizer Efficiency on Ultisol. Eurasian J. of Soil Sci.3(2): 101-107.

Gani, A. 2009. Biochar Penyelamat Lingkungan. Warta Penelitian dan Pengembangan Pertanian. 31(6): 15-16.

Gani, A. 2010. Multiguna Arang - Hayati Biochar. Balai Besar Penelitian Tanaman Padi. Sinar Tani.

Hafiz, N., Aditya, S.M., Mitu, S.F., and Rahman, A. 2016. Effect of manure type on phosphorus sorption characteristics of an agricultural soil in bangladesh. Cogent Food \& Agriculture. 2: 1-13.
Hale, S. E., Alling, V., Martinsen, V., Mulder, J., Breedveld, G. D., and Cornelissen,

G. 2013. The sorption and desorption of phosphate$\mathrm{P}$, ammonium- $\mathrm{N}$ and nitrate- $\mathrm{N}$ in cacao shell and corn cob biochars. Chemosphere. 91(11): 1612-1619.

Kasryno, F., Pasandaran, E., and Fagi, A. M. 2008. Ekonomi Jagung Indonesia. Badan Penelitan dan Pengembangan Pertanian. Jakarta.

Liang, B., Lehmann, J., Solomon, D., Kinyangi, J., Grossman, J., and O'Neill,

B. 2006. Black carbon increases cation exchange capacity in soils. Soil Science Society of America Journal. 70 : 1719- 1730.

Lehmann, J., Ramirez, J., Rondon, M., and Hurtado, M. 2007. Biological Nitrogen Fixation by Common Beans (Phaseolus vulgaris L.) Increases with Biochar additions. Biology and Fertility Soils. 43: 699-708.

Lehmann, J. and S. Joseph. 2009. Biochar for Environmental Management Science and Technology. Earthscan. London.

Maulana, D., Sarno, S., dan Nurmiaty, Y. 2014. Pengaruh Aplikasi Asam Humat dan Pemupukan Fosfor terhadap Serapan Unsur Hara $P$ dan K Tanaman Tomat (Lycopersicum esculentum). Jurnal Agrotek Tropika 2(2): 302-305.

Mulyani, A., Rachman, A., dan Dairah, A. 2010. Penyebaran Lahan Masam, Potensi dan Ketersediaannya Untuk Pengembangan Pertanian. Prosiding Simposium Nasional Pendayagunaan Tanah Masam. Pusat Penelitian dan Pengembangan Tanah dan Agroklimat. Bogor.

Prasetyo, B. H. dan Suriadikarta, D. A. 2006. Karakteristik, Potensi, dan Teknologi Pengelolaan Tanah Ultisol Untuk Pengembangan Pertanian Lahan Kering di Indonesia. Jurnal Litbang Pertanian. 2(25): $39-46$.

Rosmarkam, A., dan Yuwono, N.W. 2002. Ilmu Kesuburan Tanah. Kanisius. Yogyakarta.

Solaiman, Z. M., and Anwar., H.M. 2015. Aplication of Biochars for Soil Constraints: Challenges and Solution. Pedosphere. 25(5): 631- 638.

Tambunan S., Siswanto B., Handayanto E., 2014. Pengaruh Aplikasi Bahan Organik Segar dan Biochar terhadap Ketersediaan P dalam Tanah di Lahan Kering Malang Selatan. Jurnal Tanah dan Sumberdaya Lahan. 1(1): 85-92. 
Widowati. 2010. Produksi dan Aplikasi Biochar/ Arang dalam Mempengaruhi Tanah dan Tanaman. Disertasi. Universitas Brawijaya. Malang.
Widowati, W., Asnah, A., dan Sutoyo, S. 2012. Pengaruh Penggunaan Biochar dan Pupuk Kalium Terhadap Pencucian dan Serapan Kalium pada Tanaman Jagung. Buana Sains 12(1): 83-90. 